\title{
The MacDonald Lordship and the Bruce Dynasty, c.1306-c.1371
}

\author{
Michael A. Penman
}

\section{Introduction}

Historians cannot help but detect the eddy of irony flowing through the history of relations between the MacDonald lordship and the Bruce dynasty. The two families were thrown together by their shared opposition to the Comyns and their Macdougall allies, but in an alliance which seems to have at first transcended tensions of Irish Sea and west-coast lordship bubbling in the late thirteenth century. The Bruce lineage - and with it the Scottish kingdom - would of course quite literally be saved by the succour and military support provided by the MacDonalds and other Gaels from c.1306 to c.1314. Yet Bruce's engagement with the MacDonalds as 'Robert I' may have involved him, in part, in forceful intervention in that kindred's own internal power struggles just as it helped them to settle their local feud scores. In turn this may have further obligated Robert's commitment to a campaign which nearly destroyed the Bruce dynasty, the invasion of Ireland of 1315-18.

Thereafter MacDonald-Bruce co-operation, or more tellingly their uneasy subject-lord relationship, foundered on issues of patronage, ambition, obligation and trust. Despite a record of joint endeavour which leant itself readily to chivalric aggrandisement and poetic celebration, after 1332 the MacDonalds felt concord with England during renewed war against the Bruce Scots had more to offer. The title of Rí Innse Gall, 'dominus Insularum', was indeed adopted (1336-) in the early stages of this conflict and John, first Lord of the Isles, sought to enhance his autonomy from the jurisdictions of the Scottish Parliament and Crown officers by means of alliance with Edward III (and, until 1356, Edward Balliol). The second and last Bruce king, David II, would spend decades struggling to assert his authority over much of his territorial nobility: this would include the MacDonald lordship which would 
be forced to accommodate a partial Macdougall restoration in the west and make a first, formal submission to royal power at Inverness in 1369. However, in truth, David was far more concerned and constrained in his final years of rule by attempts to wrangle the mainland families which had first been favoured by his father as, really, a regional check upon the MacDonalds, namely the Stewarts, Campbells and the Earls of Ross.

In hindsight, these events foreshadow the patterns of succeeding centuries of CrownMacDonald interaction, not least in the lordship's westward orientation, oft-disputed succession and willingness to seek out English support, set against the Crown's ongoing search for a trustworthy policeman or gatekeeper for the Western Isles lords. It might be suggested that in this context, any ruler and dynasty that emerged from the Wars of Scottish succession to hold the throne would have inevitably stumbled in dealings with the MacDonalds and the wider Gael. And yet, might it be speculated that this history still represents something of a record of failure or a missed opportunity for the Bruce kings, especially Robert I?

\section{The First Wars of Independence, c.1286-c.1330 ${ }^{1}$}

The famous and curious 'Turnberry Band' of September 1286 may at once reflect this intermittent clash of Bruce-MacDonald adherence and ambition. Sealed at the sea-castle caput of their recently acquired ancient earldom, the Bruces had here gathered a substantial aristocratic following to pledge support 'in all their affairs' to Richard, the 'Red' second de

\footnotetext{
${ }^{1}$ For the broad background of events in this period not otherwise separately referenced below see: G.W.S. Barrow, Robert the Bruce and the Community of the Realm of Scotland (Edinburgh, $4^{\text {th }}$ edition, 2005); R. Andrew MacDonald, The Kingdom of the Isles: Scotland's Western Seaboard, c.1100-c.1336 (East Linton, 1997), ch. 6; M. Brown, The Wars of Scotland, 1214-1371 (Edinburgh, 2004), ch. 12; S. Boardman, The Campbells, 1250-1513 (Edinburgh, 2006), ch. 2.
} 
Burgh Earl of Ulster, and his neighbour, Thomas de Clare of Thomond (whose kin Robert Bruce of Annandale, the Competitor, had wed). ${ }^{2}$ Yet in doing so, the Bruces may have acted to compel two of those present, Angus Mòr of Islay and his eldest(?) son, Alexander, to cease their kindred's recurrent armed interference with galloglass in Ulster and Connacht in support of (and sometimes against) such Irish Gaels as the O'Neills, O'Conors and O'Donells (since the $1250 \mathrm{~s}$, and as recently as in fighting in $1285-6){ }^{3}$ In return the Bruces surely secured wide promises of support in their future endeavours relating to the Scottish kinship (a controversy in which Edward I was not yet involved) to be repaid, presumably, by their future and, with any luck, royal generosity.

As earls of Carrick and rightful lords of Upper Glenarm (Larne) the Bruces had married directly into this complicated Irish Sea world, an inheritance rendered all the more personal for the future Robert I by being fostered in childhood to Gaelic kin - probably along with his four brothers to the Carrick relatives, the O'Neills of Tyrone - and both of his marriages: first (c.1293?) to a daughter of Duncan, earl of Mar, who had himself taken a MacRuaridh of Garmoran as his second spouse; and second (1302) to Elizabeth de Burgh,

\footnotetext{
${ }^{2}$ Documents Illustrative of the History of Scotland, ed. J. Stevenson (2 vols., Edinburgh, 1870), i, no. 12. The other sealers were Patrick, earl of March, and his three sons; Walter Stewart, earl of Menteith, and his two sons; Bruce of Annandale and his sons Bruce earl of Carrick and Richard; James the Steward and his brother, John. Robert Bruce (VII), future king, first appears in the historical record as a witness to an undated gift by Alexander of Islay to Paisley Abbey, alongside his father, the bishop of Argyll and minor figures of Carrick, Kintyre and Arran [Registrum Monasterii de Passelet (Maitland Club, Glasgow, 1832), pp. 128-9].

${ }^{3}$ John A. Claffey, 'Richard de Burgh, Earl of Ulster (c.1260-1326)', unpublished PhD, University College of Galway, 1970, pp. 42-72, 103-13; S. Duffy, 'The Bruce Brothers and the Irish Sea World, 1306-29', in idem ed., Robert the Bruce's Irish Wars: Invasions of Ireland 1306-1329 (Stroud, 2002), pp. 45-71, at 54-63. The Band coincided with a 'great hosting' in 1286 by Earl Richard against his enemies in Ulster/Connacht. In 1256 and 1260 Henry III of England had blockaded Angus Mòr and other Isles kindreds; in 1263, Mòr and the Irish had invited Haakon IV's invasion of Scotland to divert to Ireland; in 1264, Alexander III of Scotland had taken Alexander of Islay as a hostage.
} 
daughter of the Red Earl. ${ }^{4}$ But if this gave Robert Bruce and the sons of Angus Mòr substantial common grounds of experience and outlook, the political realities of the next two decades proved to be far more difficult for the younger Robert Bruce to navigate, underscoring the essential difference between regional and regnal ambitions.

The MacDonalds and the Bruces alike found that English overlordship brought its short-term opportunities and compromises. Between 1293 and 1295 both families appealed to Edward I against legal decisions by the regime of John I (Balliol). For Alexander of Islay this furthered local territorial concerns, enabling him to make headway against Alexander Macdougall of Lorn, his father-in-law and the new sheriff of Lorn; Islay's father, Angus Mòr (d. c.1293-4), had simply exploited the remoteness of his lands and stayed away from court when official interference loomed. ${ }^{5}$ Conversely, Robert Bruce as the new earl of Carrick (1293-) with estates to inherit in England, too, could not avoid a formal submission to the new vassal King John. Predictably, this drew both MacDonalds and Bruces (and most of the other Scottish sealers of the Turnberry Band) to pledge their loyalty to Edward I when war broke out in 1296. Alexander of Islay and his younger brother, Angus Og, emerged as the English occupation's chief sea-borne adherents in the west, supported by Sir John Menteith at Dumbarton. Ordered by Edward I to seize Kintyre for Malcolm Macquillan [le fitz Engleys], the MacDonalds also surely found themselves able to begin occupying Macdougall and MacRuaridh lands and castles even without any formal forfeiture and re-grant by the English king. ${ }^{6}$

By contrast, the younger Bruce (in)famously vacillated. Summer 1297 found the MacDonalds under attack by Macdougall and MacRuaridh naval forces with Alexander

${ }^{4}$ Barrow, Robert the Bruce, pp. 183-4, 430-1 n26-32. Duncan of Mar wed Christina [MacRuaridh] of the Isles.

${ }^{5}$ Rot. Scot., i, p. 21; CDS, ii, no. 236; MacDonald, Kingdom of the Isles, pp. 163-4.

${ }^{6}$ Rot. Scot., i, p. 216; CDS, ii, nos 235-6; CPR Edward I, iii, pp. 52, 200; Stevenson, Documents, i, no. 390 (a grant of $£ 100$ of lands by Edward I) and ii, pp. 189-91, 436. 
himself (or a cadet kinsman of the same name) perishing in one such assault in 1299 while his kindred were obliged by Edward I to co-operate at sea with their former feud enemies from Ireland, the Bissets and MacSweens. ${ }^{7}$ But Bruce's credibility would be seriously undermined by one false start rebellion (1297), followed by a period of open resistance (1298-1300) as Guardian alongside the Comyns and their adherents (including the Macdougalls), and then a final desperate submission to Edward I in return for vague acknowledgement of his right to pursue the Scottish kingship (1302).

During all of this, Irish military support for Edward I threatened to cut a swathe across both MacDonald and Bruce lordship concerns. Macdougall naval activity and, from 1296, the Earl of Ulster's provision of men, horses, arms and victuals to English forces in Scotland (though often begrudging and well short of initial levies), conspired to curtail MacDonald galloglass activity in Ireland, if not to cut if off completely. ${ }^{8}$ Indeed, Earl Richard's possible role in soliciting marriages for his sister to Sir James Steward (1296) and then his eldest daughter to Robert Bruce (1302), surely with the blessing or initiative of Edward I, seems designed to revive some of the protection against mercenaries first subscribed to by these

\footnotetext{
7 'Alexander MacDonald, that person who was the best for hospitality and excellence that was in Ireland and in Scotland, was killed, together with a countless number of his own people who were slaughtered around him, by Alexander Macdougall' [The Annals of Loch Cé (1014-1590), ed. W.M. Hennessy (2 vols., RS, London, 1871), i, p. 521; The Annals of Ulster, eds. W.M. Hennessy and B. MacCarthy (3 vols., Dublin, 1887-1901), ii, p. 393]. That this was Alexander of Islay is accepted by: W.D. H. Sellar, 'MacDonald and MacRuari pedigrees in MS 1467', West Highland Notes and Queries, xxviii (1986), pp. 3-15; MacDonald, Kingdom of the Isles, p. 168; C. McNamee, Robert Bruce: our most valiant Prince, King and Lord (Edinburgh, 2006), p. 80; and Brown, Wars of Scotland, 259. However, S. Duffy, 'The 'Continuation' of Nicholas Trevet: a new source for the Bruce invasion', Proceedings of the Royal Irish Academy, xci (1991), pp. 303-15, at 311-12, prefers the Alexander killed in 1299 to be a brother of Angus Mòr (with Alexander [Og] of Islay dying later, perhaps at Faughart in 1318). W.D. Lamont, 'Alexander of Islay, son of Angus Mór', SHR lx (1981), pp. 160-9 at 167-9, similarly argues against Alexander's death in 1299. Acts of the Lords of the Isles, p. 281, explores all possible options.

${ }^{8}$ Claffey, 'Richard de Burgh, Earl of Ulster', pp. 123-8, 138-61, 166-253.
} 
lords at Turnberry in $1286 .{ }^{9}$ With Bruce now restored to King Edward's peace (serving in Parliament and as sheriff of Ayr) such pressure could be brought to bear within a circle of alliance and lordship.

At this juncture, c.1302, Bruce's match might easily have been strengthened in this direction by further offers of marriage between the houses of Bruce or Stewart (or Campbell) and the sons/daughters of Alexander of Islay or their uncle, Angus Og (whose mother was a Campbell of Lochawe). However, it must be acknowledged that even without Edward I's military success and the collapse of the Balliol-Coymn Guardianship of patriots in 1303-4, the resulting Macdougall and MacRuaridh exile, and then a fresh eruption of Bruce ambition in 1306, the MacDonalds may still have preferred to pursue their immediate territorial aims. Angus and his nephews all seem to have made valuable marriage alliances with Irish native kindreds and galloglass by c.1308-9, the year to which secondary authorities often alternatively date Alexander of Islay's death: Alexander's children would give rise to the Mac Domhnaill galloglass rivals to the O’Neills and their MacDonald allies. ${ }^{10}$

Nevertheless, there is no doubt about the extent to which the loyalties and fortunes of the MacDonalds were revolutionised by the actions of Bruce in 1306. If Edward I's clear preference by 1305 for the Comyn affinity as his officers in his occupied Scottish land including the rehabilitated Macdougalls - was not enough to alienate the MacDonalds, then Bruce's slaughter of Comyn of Badenoch, his seizure of the throne and flight west in the face of both English and vengeful Scottish forces, threw his fledgling dynasty into the arms of

\footnotetext{
${ }^{9}$ C. McNamee, The Wars of the Bruces: Scotland, England and Ireland, 1306-1328 (East Linton, 1997), pp. 5-6. Earl Richard's second daughter would be married to the Earl of Gloucester/Lord of Kilkenny.

${ }^{10}$ Acts of the Lords of the Isles, pp. 281-2 [Appendix D - genealogies]; A. McKerral, 'West Highland Mercenaries in Ireland', SHR, xxx (1951), pp. 1-29; Duffy, 'The Bruce Brothers and the Irish Sea World', pp. 57-63; K. Nicholls, 'Scottish Mercenary Kindreds in Ireland, 1250-1600', in S. Duffy ed., The World of the Galloglass: Kings, warlords and warriors in Ireland and Scotland, 1200-1600 (Dublin, 2007), pp. 86-105, at 95-8.
} 
western lords and their mercenary forces. It should never simply be assumed, though, that the support of the MacDonalds and other Gaelic lords was given naturally or even in friendship. 'Robert I' undoubtedly had to pay a price.

No charters from King Robert to any MacDonald lord are extant in full from this period. But seventeenth-century summary indices do survive of [undated] grants to lords of that kin by the Bruce king of the Macdougall's forfeited lordship of Ardnamurchan, along with lands on Mull and Tiree, plus the former Comyn mainland lordships of Morvern, Duror, Glencoe and, crucially, Lochaber. ${ }^{11}$ In addition, Archdeacon Barbour, in The Bruce, asserts that Angus Og was 'lord of Kintyre' in $1306 .{ }^{12}$ Moreover, during the second phase of the Wars, John MacDonald, first 'Lord of the Isles' (son of Angus Og), would receive charters from both Edward Balliol (1336) and David II (1341/3) covering the lands of Kintyre, Knapdale, Gigha, half of Jura, Colonsay, Mull, Skye, Lewis, Morvern, Ardnamurchan, Glencoe and, again, Lochaber (with further specified castles, small islands, feudal casualties and resources, discussed below). ${ }^{13}$ It is surely the case that these later confirmations are closer to the full scale of MacDonald ambition and speak to territory much of which they had occupied by force since 1296 and thus lordship which Robert I may have had to concede in return for immediate shelter in 1306-7, followed by military support to aid his recovery c.1308-9. Therefore, some or all of these grants surely date to the early years of Robert's reign, say after the fall of Dunstaffnage castle in autumn 1309 (with custody given over to the Campbells), rather than to the king's wider redistribution of forfeited lands begun at the Cambuskenneth Parliament of November 1314 (from which a number of charters are

\footnotetext{
${ }^{11} R M S$, i, App. ii nos 56-8, 653.

12 A.A.M. Duncan ed., The Bruce - John Barbour (Edinburgh, 1997), pp. 143-7. That the MacDonalds had intruded on Kintyre before c.1306 is suggested by the grant issued by Alexander of Islay of Kintyre lands [Registrum Monasterii de Passelet, pp. 128-9; above n2]. ${ }^{13} C D S$, iii, no. 1182; RRS, vi, p. 505; RMS, i, App. i, no. 114 and App. ii, no. 752; Acts of the Lords of the Isles, pp. 1-4 [nos 1-3], 208-9 [A5].
} 
extant). ${ }^{14}$ In c.1306-8, promises of Bruce support for a future galloglass campaign to Ireland may also have been secured by the MacDonalds (and an O'Conor rising would erupt in Connacht at this time). ${ }^{15}$

In return for these grants, Robert I presumably secured significant military services, including vital galley power. However, that he had issued this patronage with a mixture of reluctance and short-term calculation, perhaps with an eye to revisiting any agreement at a later more stable date for his kingship, is at least suggested by his subsequent grants of key parts of this patrimony to his closest supporters. This certainly included the vast estates of Lochaber to Thomas Randolph as earl of Moray as early as 1312 (as a lord better equipped to provide mainland military power?) and may also have applied to the Stewarts (the lordship of Kintyre), the Campbells (baronies in Argyll) and the Earl of Ross (the lordship of the Isle of Skye). ${ }^{16}$

What might easily have complicated matters c.1306 was that the MacDonald lordship may have been contested and fragmented internally, a possibility not easily isolated from the family's messy genealogical debates which has evolved over time. Bruce's main grant of former Comyn and Macdougall lands was noted as being given in favour of Angus Og but the Mull and Tiree lands had been received by an 'Alexander de Insula' or 'Alexander the younger', possibly the still living elder brother, then, or his or Angus's eldest son in turn. Furthermore, Robert I's first Parliament at St Andrews in March 1309 would be attended by a 'Donald of Islay', whom Professor Barrow suggests (without any conclusive proof) may have been another elder brother (or, it might be thought, an uncle or cousin?) of both Alexander

\footnotetext{
${ }^{14}$ Duncan ed., The Bruce, p. 366; RRS, v, nos 10 [charter issued by the king at Dunstaffnage, 20 Oct. 1309], 41-3.

${ }^{15}$ Claffey, 'Richard de Burgh, Earl of Ulster', p. 294.

${ }^{16} R R S$, v, no. 389; RMS, i, App. ii, nos 61 [Skye to Hugh Earl of Ross], 661 [Kintyre to Robert Steward].
} 
and Angus. ${ }^{17}$ Donald it was who witnessed that Parliament's famous nobles' letter to the King of France, his name recorded immediately after 'John [Macdougall] of Argyll' (who would soon defect) and in anticipation of the 'barons also of the whole of Argyll and the Isles' ${ }^{18}$ Rival claims of seniority and degree, primogeniture and tanistry, might thus easily have afflicted the Isles lordship then as they would later, forcing Bruce to deal with one or more MacDonald lord or their allies.

This may explain why although in fact it was galloglass lord Malcolm Macquillan who had prepared shelter at Dunaverty Castle in Kintyre for Bruce and his dwindling party, until their flight by boat to the Irish mainland or one of the Western Isles in AugustSeptember 1306, Archdeacon Barbour instead attributes this rescue (and a flight to Rathlin) to Angus Og, perhaps as Angus did eventually assert himself as 'lord of Islay'. ${ }^{19}$ Moreover, Barbour - although influenced by Crown-MacDonald relations c.1329-75 - also hints that even once received at Dunaverty, King Robert 'was dredand for tresoun ay', perhaps a reflection of his vulnerability to the rivalries of competing local lords. ${ }^{20}$ Bruce's actual flight

${ }^{17}$ Barrow, Robert Bruce, pp. 231, 408; CDS, iv, no. 1822; Liber Sancte Marie de Melros (Bannatyne Club, 2 vols., Edinburgh, 1827), ii, no. 376; Acts of the Lords of the Isles, p. 282. Duncan accepts Barrow's argument and Donald as the elder brother and 'Lord' [The Bruce, p. 148]. McNamee's suggestion that this was a scribal error for '[Angus Og Mac]Donald, Lord of Islay' cannot account for all the other record evidence for a Donald [McNamee, Robert Bruce, p. $323 \mathrm{n} 31$ ], nor the use of this christian name in Parliament in 1309 in the same way as 'John' of Argyll. Lamont, 'Alexander of Islay', pp. 168-9, dismisses the likely existence of 'Donald'. In contrast, Duffy, 'The 'Continuation' of Nicholas Trevet', pp. 311-2, followed by D.H. Caldwell, Islay: the Land of the Lordship (Edinburgh, 2008), p. 45, argues that 'Donald' was a cousin of brothers Alexander and Angus.

${ }^{18}$ RPS, 1309/1. MacDonald, Kingdom of the Isles, pp. 187-8, argues that the complex MacDonald genealogy suggests that 'Donald' was perhaps a son of Alexander or Angus, who contested the family succession $1318 \times 1325$.

${ }^{19}$ Duncan ed., The Bruce, pp. 144-6.

${ }^{20}$ The sixteenth-century history of the MacDonalds perhaps protested too much: 'He [Angus Og] was always a follower of King Robert Bruce in all his wars.' [Highland Papers, ed. J.R.N. MacPhail (4 vols., SHS, Edinburgh, 1914), i [1337-1680], pp. 1-103, at 17]. For further discussion of the MacDonald genealogy see Caldwell, Islay, pp. 43-5, which suggests Alexander of Islay died not in 1299, but c.1309, drawing on the aforementioned MacDonald family history to relate a tale that Alexander had died after Robert I had besieged him in 
from Kintyre to the Isles in 1306 may besides have seen him pitch up, as A.A.M. Duncan suggests, at Dunyvaig castle on Islay itself to force a(nother) leading MacDonald to open negotiations about service. ${ }^{21}$

Their ambitions apparently satisfied the MacDonalds and their galloglass nonetheless proved highly motivated and effective military allies. Both Irish and Scottish sources attest to their intimidating presence in Bruce's forces after his landing in Carrick in 1307, aiding both the King's northern campaign in 1308 against Ross, the Comyns and, of course, the Macdougalls, as well as Edward Bruce's parallel surge in Galloway ${ }^{22}$; and on to Bannockburn where Barbour asserts a large body of men of the Isles, Kintyre and Argyll turned out in the vanguard of Robert I's own division. ${ }^{23}$ It seems clear that the Isles and galloglass military traditions of galley power and lightly-armoured, mounted hobelar raiding parties, familiar to the Bruces from their Carrick youth, were positively embraced and thus had profound impact upon both Bruce military tactics and, surely, some personal relations within the regime and its forces. ${ }^{24}$

Indeed, regardless of whether or not this relationship of service began in an atmosphere of dictated lordship or opportunism, it must be acknowledged that the Bruce Scots' momentum of success may have benefited from and further developed a genuine

Castle Sween in Argyll then gaoled him in Dundonald castle: this might mean that, as per Barbour's tradition, it was Alexander of Islay, not his brother Angus Og, who had handed over Dunaverty to Robert I in 1306, and thus that lord (who had a Macdougall wife) from whom Bruce feared treason. Lamont, 'Alexander of Islay', pp. 161-2, seeks to debunk this tale.

${ }^{21}$ Barbour, writing in the early reign of Robert II (1371-90), the former Robert Steward, may have been seeking to rehabilitate Angus, the father of John MacDonald, first Lord of the Isles, son-in-law of Steward, the new king (much as he played up Walter Steward and James Douglas for their successors)?

${ }^{22}$ Chron. Bower, vi, 66, states that a 'Donald of Islay' led galloglass alongside Edward Bruce in the south-west in 1308.

${ }^{23}$ Duncan ed., The Bruce, pp. 420-1.

${ }^{24}$ McNamee, Wars of the Bruces, chs 3-6; N.A.M. Rodger, The Safeguard of the Sea: A Naval History of Britain, 660-1649 (London, 1997), pp. 86-9. 
shared ethos of identity within their armed cause for the royal family and some of its key mainland supporters, as well as the MacDonalds, MacRuaridhs and other Gaels. What can be construed as mere propaganda to eastern Lowland lords and clergy (and as' fishing' to one modern historian) may have had a real resonance within the context of a "national ancestry...common language...common custom' (and common spiritual lights) shared by those whose lands marched on the Irish sea, inter-connected by marriage, tenure, lordship and saints' cult familia. The Gaelic-speaking Bruce may have been quite at home in his exile, renewing former acquaintances as well as begging further help. Historians have now firmly established these motivations as tangible long before Bannockburn, attested to by the Bruce letter to the Gaelic Irish of 1307, rumours of a liaison between the king and Christina of the Isles, and decisive Bruce and galloglass intervention in May 1313 to both take the Isle of Man (seized by the Earl of Ulster for Edward I in 1290) and attempt a galley raid into Ulster. $^{25}$

In sum, just as modern historians have recently investigated in depth the Bruces' motives for the invasion of Ireland of 1315-18, so a further reassessment of these motives and the allied influence over Scottish policy of kindreds like the MacDonalds and other Gaels may be long overdue. Bruce's debt to the MacDonalds and MacRuaridhs for their support c.1306-14, the unfulfilled aims of inheritance, territory and plunder in Ireland of these families' galloglass allies and followings, a thirst for further revenge against intercine rivals as well as exiled opponents like the Macdougalls, Macdowalls and the de Burgh Earl of Ulster, all bound within a sense of mission to throw off English overlordship, may have been equally, if not more, important than considerations of diplomatic force, supplies and strategy

\footnotetext{
${ }^{25}$ Duffy, 'The Bruce Brothers and the Irish Sea World', pp. 50-2, 62-3, 68-70; A.A.M. Duncan, 'The Scots' Invasion of Ireland, 1315', in R.R. Davies ed., The British Isles, 11001500: Comparison, Contrasts and Connections (Edinburgh, 1988), pp. 100-17.
} 
vis à vis Carlisle and Westminster, to those lords who committed themselves to the Irish enterprise.

It is interesting to speculate that the MacDonalds were not completely united in their support of the Irish campaign under Edward Bruce's banner. March 1315 had seen Edward II order John of Argyll, captain of naval forces in the Irish Sea and responsible for the retaking of the Isle of Man earlier that year, to take into his peace a number of Islesmen, including a 'Donald of Islay'. Thus when Robert I launched his famous assault across the Tarbert peninsula of northern Kintyre in May-June 1315, timed to coincide with his brother's descent on Ulster and with the support of his returning fleet of transport galleys, the King may have sought to publically fulfil an ancient Norse prophecy: that whosoever could cross this isthmus in ships with sails unfurled would be master of the Western Isles. ${ }^{26}$ Yet in reality Robert may have done so by way of overawing both former enemies like the Macdougalls but also in support of the dominance of one of several rival MacDonald lords.

Frustratingly, the Irish annals do not firmly identify the MacDonald leader who would be slain at Faughart on 14 October 1318 (destroyed by an enemy which included his galloglass kinsman and now rival, Aed O’Domhnaill): he fell alongside Edward Bruce, a MacRuaridh chieftain and scions of the houses of Stewart, Soules, Mowbray and Menteith. Only one annalist, that of Inisfallen, provides a christian name for this lord as 'Alexander $\mathrm{M}[\ldots]$, whilst those of Ulster and Connacht record the fallen as 'Mac Ruaidri ri Innse Gall [and] MacDomnaill ri Oirir Gaedeal [Argyll]'. As a result of this uncertainty Alexander of Islay or a namesake son, and even Angus Og himself or, if the latter had died c.1315x1318, his heir in turn (Alexander?), have all been suggested as possible candidates. ${ }^{27}$ A separate

\footnotetext{
${ }^{26}$ Rot. Scot., i, pp. 122, 132; Duncan ed., The Bruce, pp. 560, 564-5.

${ }^{27}$ The Annals of Inisfallen, ed. S. Mac Airt (Dublin, 1951), pp. 428-9; The Annals of Connacht (AD 1224-1554), ed. A.M. Freeman (Dublin, 1944), pp. 252-3; Acts of the Lords of the Isles, p. 281; Duffy, 'The Bruce Brothers and the Irish Sea World', p. 61; McNamee,
} 
'Donald' of Islay is also stated to have been killed in the battle by another Irish source. ${ }^{28}$ It seems likely, however, that Angus or his son in fact ruled as lord of Islay until c.1330 as the father or elder brother of the John, first Rí Innse Gall, who would be so at odds with David II and live on until 1387. Whoever had acted as chief since c.1306 seems to have combined participation in Edward Bruce's campaigns with the assertion of their lordship over the conquered Macdougall territories as well as, perhaps, over their own family cadets and patrimony. Thus it is also possible that the chief's death at Faughart heralded a minority and sparked a further internal MacDonald power struggle.

If it was in truth only after this defeat or later in the 1320s that Angus Og, or one of his sons, emerged as unchallenged lord of Islay, this lord's potentially more troubled relations with Robert I (who may thus have favoured Alexander or Donald) may explain much of the apparent unravelling of the Crown-MacDonald alliance in the second half of Bruce's reign. Yet the marked shift in Crown policy towards the Western Isles and the MacDonalds after 1318 must explain this in greater measure. Even before the disaster at Faughart, the Isles kindreds may have become dissatisfied with the Irish campaign. There is no extant charter evidence to suggest that Edward Bruce rewarded his galloglass supporters with seized AngloNorman lands in Ireland (although this was surely something he planned to do once established and which might have enabled Robert I to compensate kin like the MacDonalds as he looked to rearrange his early west-coast and allied Highland land grants). ${ }^{29}$ Mid-1316 had seen Edward Bruce's forces capture Northburgh castle on the north coast of Donegal, a stronghold erected by the Earl of Ulster to discourage galloglass incursion from the Western

Wars of the Bruces, pp. 185-6; MacDonald, Kingdom of the Isles, pp. 186-7. Duncan ed., The Bruce, pp. 667-77, mentions a Mowbray, a Soules, a Stewart and Carrick men killed at Faughart but no MacDonald or MacRuaridh chiefs.

${ }^{28}$ Duffy, 'Continuation' of Nicholas Trevet', pp. 311-12, 314 [Donald].

${ }^{29}$ Duffy, 'The Bruce Brothers and the Irish Sea World', p. 62. 
Isles (and a harbour used by Macdougall's ships). ${ }^{30}$ However, the main thrust of the 1316 and 1317 seasons saw the invaders and their erratic native vassals (including the MacDonalds' allies, the O'Conors) push further into central and southern Ireland on increasingly risky, illsupplied chevauchées, away from the familiar pickings of Ulster and Connacht. Then there were delays in the dispatch of Scottish mainland reinforcements to Edward Bruce in 1318 as the focus of Robert I and his government turned east to fending off English attempts to recover Berwick-upon-Tweed, taken by the Scots in April that year, and to stabilising the Bruce settlement and succession. The feud nature of the Irish wars may also have been considerably lessened for many parties after autumn 1317 by the natural death of John Macdougall of Argyll. ${ }^{31}$

More generally in the wake of Faughart, after decades of war there may have been a natural recoiling by the King and his Lowland subjects away from the violence, frequent treachery and terrible cost of such galloglass assaults. Following the Anglo-Scottish truces which punctuated the period 1319-27 any strategic re-intervention by Robert I in Ireland would see him revert, in the spirit of the Turnberry Band of 1286, to engage not with the native Irish and galloglass but with the de Burgh earldom of Ulster: here in 1327-8 he used intimidation to extract victuals and to install his underage nephew, William de Burgh (hinting at a lingering, influential inheritance role for Queen Elizabeth (d. 1327) after the death of her father, Earl Richard, in 1326). ${ }^{32}$ This approach underscored the Crown's shift to what might

\footnotetext{
${ }^{30}$ Claffey, 'Richard de Burgh, Earl of Ulster', pp. 259-60; S. Duffy, 'The Bruce Invasion of Ireland: a Revised Itinerary and Chronology', in idem ed., Robert the Bruce's Irish Wars, pp. 9-44 for what follows and p. 29 for Northburgh.

${ }^{31} C D S$, iii, nos 490, 912. MacDonald commitment to the galloglass cause is underlined by the reported death in battle in Derry in 1318, of another unnamed MacDonald lord alongside Seoan, son and heir of Domnaill Ó Néill [Annals of Loch Cé, i, pp. 594-5; Duffy, 'The Bruce Brothers and the Irish Sea World', p. 61].

${ }^{32}$ Nicolson, 'A Sequel to Edward Bruce's Invasion of Ireland', in Duffy ed., Robert Bruce's Irish Wars, pp. 153-61; McNamee, Wars of the Bruces, pp. 242-6.
} 
best be described as a western-approaches policy intended to at once contain and keep at arm's length Isles kindreds headed by the MacDonalds and MacRuaridhs.

This new tack was characterised by royal marriages for western and northern mainland families whose holdings and influence either marched upon or were now increased by royal grant around Argyll and the Isles lordships. This was a group headed by Walter Steward (married to Robert I's daughter in 1315 but who became lord of Kintyre in the 1320s), Hugh Earl of Ross (married to Robert's sister by c.1315, who became lord of Skye, and whose daughter wed Thomas Randolph, Earl of Moray and lord of Lochaber), Neil Campbell of Lochawe (wed to another sister of the king and raised to be earl of Atholl) and the Crown ward, William, Earl of Sutherland. ${ }^{33}$ These men and their close adherents also received key regional offices and strongholds alongside other western Crown allies such as the Menteiths, the Earl of Lennox and Malcolm Fleming of Biggar. ${ }^{34}$ The Crown presence in the region was also intensified, with retiring Chancellor, Bernard of Arbroath, transferring to be Bishop of the Isles in 1328, housed in a new diocesenal church planned for the Isle of Man. ${ }^{35}$ A sheriffship of Argyll was established sometime c.1315-25 and Robert I consolidated considerable investment in castles with administrative and trading roles at Dunstaffnage, Dunaverty, Tarbert and, to a lesser extent, the Carrick caput of Turnberry, as

\footnotetext{
${ }^{33} R R S, \mathrm{v}$, nos 391 [Steward]; 246 [Ross]; 27, 46, 128, 366, 374, 393 [Campbell]. RMS i, App. ii, nos 168, 218-22, 363, 661, 692 (an appoyntment with the barons of Argyll) [Steward]; 11, 45, 49, 50, 58-61, 370, 380-1, 383 [Ross]; 152, 351-3 362, 368, 642 [Campbell]. ER, i, pp. 24, 57 [Campbell ship to Tarbert], 74 [Dugal Campbell, sheriff of Argyll]. The Scots Peerage, ed. J.B. Paul (9 vols., Edinburgh, 1904-14), viii, p. 324 for Sutherland.

${ }^{34} R R S, \mathrm{v}$, nos 239, 419, 501-2, 546 [Menteith]; 11, 118, 194, 468 [Lennox]; 553 [Fleming]. $R M S$, i, App. ii, nos 350, 514, 585 [Menteith]; 204, 418 [Lennox]; 194-6 [Fleming]. ER, i, pp. 178, 180, 257, 258. For discussion of this royal party see Boardman, The Campbells, p. 45.

${ }^{35} E R, \mathrm{i}$, p. 114; RRS, v, no. 358. Robert I reserved the patronage of the see to himself on 20 December 1324 [D.E.R. Watt and A.L. Murray eds., Fasti Ecclesiae Scoticanae Medii Aevi Ad Annum 1638 (Edinburgh, 2003), p. 262].
} 
well as at his own personal manor house at Cardross, near Dumbarton, where he and Randolph also retained galleys (enhancing access to Ulster). ${ }^{36}$

Indeed, what turned out to be the last few months of his reign also saw Robert I apparently extract by personal itinerary and patronage further naval and military services from west coast and south-west mainland kindreds. ${ }^{37}$ To date there has been a general historical consensus that this was a wise and quite impressive fortification of westward defences in anticipation of renewed war against England, under Edward III, and the Disinherited, a move sensitive to questions of loyalty to the Bryce dynasty in the west and south-west. It might also seem to reflect attempts to build a strong network of patronage in the west through which Robert I and, after his death in 1329, the Guardianship of Randolph (d.1332), could look to effectively police and raise revenues from the west. ${ }^{38}$ However, in reality it might be prudent to acknowledge the possibility that many of these Bruce grants in return for the services of oared-galleys and spearmen were, at best, nominal.

For as had Richard, Earl of Ulster, Bruce may have found it otherwise difficult to extract any rental income or alternative services from what were remote and very often disturbed, relatively impoverished and highly militarised regions. ${ }^{39}$ Decades of conflict and plunder, harsh winters and wet summers, lingering livestock pandemic and limited production of new Scottish royal specie only after 1318, may have combined to drive lords and men in Scotland generally to the point where tenure confirmations and fresh grants in

\footnotetext{
${ }^{36}$ ER, i, pp. 52-7, 127 [Tarbert Castle, also with mooring for the 'great ship']; 56, 123, 127, 149, 269 [Cardross]; 52, 196 [sheriff of Argyll, Dugald Campbell]; 38 [Dumbarton Castle, constable William Fleming]; 53 [Tarbet west town and peel]. RMS, i, App. ii, nos 368, 462 [Dunstaffnage Castle, constable Arthur Campbell]. J.G. Dunbar and A.A.M. Duncan. 'Tarbert Castle', SHR, 1 (1971), pp. 1-17.

${ }^{37} R R S, \mathrm{v}, \operatorname{nos} 362$ to $374(\mathrm{~A}) ; R M S$, i, App. ii nos 607-10, 612-15, 617, 622-4. A total of two galleys, four armed, four archers and a spearman were secured on Robert's Whithorn pilgrimage of Feb.-Apr. 1329.

${ }^{38} R R S$, v, pp. 48-61 ['Services and Returns'], esp. pp. 52-4.

${ }^{39}$ Claffey, 'Richard de Burgh, Earl of Ulster', pp. 189, 282.
} 
return for specified military services may have been the only bearable demands of lordship (as short at 40 days a year, infrequent, deliverable by proxy or avoidable). ${ }^{40}$ Robert's Parliament of December 1318 had gone to some lengths to legislate for the quality and preparedness of subjects' arms and armour in time of war throughout the realm, details which must in part reflect royal experience of west coast warfare. ${ }^{41}$ Yet in reality Robert could perhaps only hope for an uneven return on his patronage with a dwindling military muster response the further north and west his summonses would have to travel out from central Scotland, beyond the established militarised followings of such key councillors and captains as the Campbells and Sir John Menteith.

By the mid-1320s this was undoubtedly the case, too, as regards the remaining lands held of the Bruce monarchy by the MacDonalds and their regional adherents where cadets and lesser kindreds were militarised for galloglass purposes. This reflected just how limited the royal writ was beyond the Strewarty, Lennox and central Argyll and the immediate vicinity of any more westward Crown castles. In March 1325, relations with the MacRuaridhs collapsed and Parliament forfeited their lands. ${ }^{42}$ It seems legitimate to ask, however, if this judgement was ever actually enforced on the ground by royal officers before the MacRuaridh 'restoration' in the later 1330s-early 1340s: did this kindred ever really face royal justice and exile? It is difficult to escape the sense, too, that in the last few years of Robert I's life, the MacDonalds, probably under Angus Og or his son, were headed down a similar road towards confrontation with their former Bruce masters - particularly over royal

\footnotetext{
${ }^{40}$ McNamee, Wars of the Bruces, pp. 13-14; Timothy Newfield, 'A cattle panzootic in early fourteenth-century Europe', Agricultural History Review, 57 (2009), pp. 155-190.

${ }^{41} R P S, 1318 / 29$.

${ }^{42}$ Ibid., 1325/2; RMS, i, App. ii, no. 699. This may explain visits to Tarbert in that year by the king, Douglas and the Bishop of St Andrews; 12 May 1325 had found the king at Cardross, perhaps returning from the west [ER, i, pp. 56, 58; RRS, v, no. 274(A)]. Caldwell, Islay, p. 47 , is not alone in suggesting that the 'Roderick of Islay' noted (in seventeenth-century transcripts) as forfeited in parliament was in fact a MacDonald, perhaps John's elder brother.
} 
tax collection between 1326 and 1331 - yet unlikely to face physical displacement: unless at the hands of the unexpected fifth column of the Macdougalls, who might call upon residual local loyalties if restored as part of the 1328 Anglo-Scottish peace process; or with mutual de Burgh aid for the Bruce dynasty in rooting out outlaws active in each other's lands. ${ }^{43}$ It remains highly debatable that royal favour at this point in the form of a belated marriage, high office or restored mainland holdings would have prevented the alienation of CrownMacDonald relations.

\section{The Second Phase of the Wars, c.1330-7144}

In September 1335, the decision of John of Islay to ally with Edward Balliol and Edward III in return for confirmation of the extensive regality of former Macdougall holdings seemed to follow the precedent of MacDonald choices of allegiance in 1296 and 1306: taking advantage of war, the wider political crisis and the power vacuum resultant from the deaths of Robert I, Bishop Bernard and Thomas Randolph, among others, as well as the murder of Earl William of Ulster (1332) and the English capture of the Isle of Man (1333), to forward MacDonald regional lordship priorities. ${ }^{45}$ In truth, the situation may have become more complex with Lord John preferring to remain aloof from the fighting for as long as possible and prepared to consider what both sides had to offer before responding to pressure from various directions.

\footnotetext{
${ }^{43}$ S. Cameron and A. Ross, 'The Treaty of Edinburgh and the Disinherited (1328-1332)', History, lxxxiv (1999), pp. 237-56.

${ }^{44}$ For the broad background of events in this period not otherwise separately referenced below see: Brown, The Wars of Scotland, ch. 12; M. Penman, David II (East Linton, 2004); 'MacDonald family' entry in Oxford Dictionary of National Biography (60 vols., Oxford, 2004), eds. H.C.G/ Matthew and B. Harrison, 35, pp. 202-4; Boardman, The Campbells, ch. 3; A. Beam, The Balliol Dynasty, 1210-1364 (Edinburgh, 2008).

${ }^{45}$ CDS, iii, no. 1182 .
} 
By the end of 1334 the Bruce dynasty might all too easily have appeared doomed. Only a handful of royal castles, including Dumbarton, Dunstaffnage and Tarbert, remained in the control of supporters of David II, with the child king himself exiled to France while his heir presumptive, Robert Steward, struggled to retain a foothold in his Stewarty lands. In late summer 1335 Anglo-Balliol naval forces from Ireland assailed the Steward's Clydeside lands with sufficient menace as to force that lord to briefly submit to Edward III and Balliol. ${ }^{46}$ Crucially, although this may have facilitated (or secured earlier) MacDonald intrusion into Kintyre, these same forces could now threaten both MacDonald galloglass routes to interests across the Irish Sea and their Hebridean lordships. This may explain why John was unconvinced by the reported overtures of Bruce Guardian John Randolph, earl of Moray, at Tarbert in summer 1335. Randolph, after all, may have had a weak hand to play, unable to make concessions over Lochaber and Glencoe (while the Strathbogie earl of Atholl remained on the Bruce Scots' side until late August) or over Kintrye and Skye (for fear then of alienating Robert Steward and the earl of Ross). ${ }^{47}$

Edward Balliol and Edward III had no such qualms about granting away enemy lands to the MacDonalds and by 12 September John had made his treaty with the English King and his vassal. However, he maintained no desire to become embroiled in the mainland conflict and coupled his switch of allegiance to adoption of the title of Lord of the Isles (21 September 1336). ${ }^{48}$ It is surely the case that the Balliol grant of MacDonald titles, in conjunction with the coveted Macdougall baronies, given in a Parliament at Perth on 12 September 1336 attended by Edward III, must also have been accompanied by firm

\footnotetext{
${ }^{46}$ Ibid., no. 1174; Sir Thomas Gray, Scalacronica, 1272-1363, ed. A King (Surtees Society, Woodbridge, 2005), pp. 99, 100-1; Adae Murimuth (1275-1347) Continuato Chronicum Robertus de Avesbury de Gestis Miarbilibus Edwardi Tertii, ed. E.M. Thompson (RS, London, 1889), pp. 299-301.

${ }^{47}$ Chron. Bower, vii, pp. 111-3; Chron. Wyntoun, vi, pp. 52-3.

${ }^{48}$ Acts of the Lords of the Isles, pp. 1-4 [nos 1-3, esp. W.D.H. Sellar's title analysis, note no. 3].
} 
assurances that John of Argyll's namesake grandson and heir, then a youth in exile in England, would not receive Anglo-Balliol backing to recover his estates. John had thus rather smartly neutralised the threat from both Bruce and Balliol directions (or so he may have thought). ${ }^{49}$ Although John did have to surrender hostages - his 'next cousins in minority' until he had a lawful son of his own - Edward Balliol promised to be his heir's godfather (just as Edward I had been his). John's Anglo-Balliol submission also seemed to allow him leeway in his continued dealings in Ireland: on 24 May 1338, for example, Edward III would accede to John's request that his ally in Ireland, Hugh Bisset, be granted lands in the once Bruce-held barony of Glenarm in Larne. ${ }^{50}$

That Lord John remained largely removed from the military and political machinations of the war and focussed upon Hebridean concerns is reflected in two further occurrences; first, his (perhaps quite late) marriage c.1337 to his cousin, Amy MacRuaridh, sister of Ranald/Reginald of Garmoran, by whom he would sire several sons ${ }^{51}$; and, second, by Lord John's apparently simple return to David II's peace following the 17-year-old king's return from exile in June 1341. Probably at Ayr about 9 November that year, it was surely John who was present to receive David's confirmation of MacDonald possession of Islay, all of Kintyre, Gigha, Jura, Colonsay, Morvern and Morenish in Mull), lands granted to them (early?) in the reign of Robert I and then again by Edward Balliol in 1336. Further, now lost, royal charters might have been issued to John at this time, perhaps including a fresh grant of Lochaber (without Balliol's limitation of only wardship over Lochaber until the Strathbogie

${ }^{49}$ S. Boardman, 'The Tale of Leper John and the Campbell Acquisition of Lorn', in E.J. Cowan and R.A. MacDonald eds., Alba: Celtic Scotland in the Medieval Era (East Linton, 2000), pp. 219-47, at 232.

${ }^{50}$ CDS, iii, no. 1272; Calendar of Papal Rolls: Edward III, 1338-49, pp. 81-2, 88. As John, 'whose steady loyalty and exposure to peril in defense of his rights [Edward III] well knows.' Edward III also granted John (and up to 100 men and ships) safe-conducts to England [Rot. Scot., i, pp. 516, 534, 535].

${ }^{51}$ Highland Papers, i, p. 74; Acts of the Lords of the Isles, p. 242 [B22]. A Papal dispensation was issued for this match on 4 June 1337; so much for the MacRuaridhs' 1325 forfeiture? 
heir came of age) while John Randolph, earl of Moray and lord of Lochaber, was still a prisoner of England. ${ }^{52}$ John of the Isles' brother-in-law, MacRuaridh, was also 'restored' to royal favour and his lands by David about this time. ${ }^{53}$ John was so grateful as to send the king a gift of two prize hawks sometime in the year before June $1342 .{ }^{54}$

The willingness of David and his close councillors to allow John to continue in possession of all these territories is explained by the king's more pressing need to challenge the accumulated power of key regional mainland families who had also benefitted from the vacuum of war and the royal minority and absence, not least William, Earl of Ross, and Robert Steward, the royal heir presumptive. By contrast with these lords David may have reasoned that the MacDonalds had done far less since c.1332 to directly undermine Bruce authority, despite their alliance with England, and Lord John (and Ireland) remained beyond the king's immediate sphere of interest. ${ }^{55}$ Besides, since the mid-1330s or earlier, territorial tensions between the Stewartry and Lordship, particularly around the Clyde and Kintyre, had probably escalated into an open feud which was now of short term value to the Crown. David's grant to John c. November 1341 may, then, as with several other acts of patronage at that time, have been designed to put regional pressure on the Steward.

\footnotetext{
${ }^{52} R M S$, i, App. i, no. 114; RRS, vi, p. 505. This favours the view that the transcribed and abridged copy of the grant to MacDonald has mistakenly turned 'John, son of Angus de Insulis' into 'Angus, son of John de Insulis' [noted in Acts of the Lords of the Isles, p. 207, A1]. At Ayr on 9 and 11 November 1341 respectively David had granted Sir Malcolm Fleming the earldom of Wigtown and Sir William Ramsay the lands of Carnock [RRS, vi, nos. 39-40].

${ }^{53}$ Ibid., nos 73, 485.

${ }^{54} E R$, i, p. 511, perhaps intended for the royal falcon house at Cardross [ibid., i. p. 127]. The timing of this gift from 'Johannis de Insulis' indicates that c.Nov. 1341 David had recognised Lord John's position, not an 'Angus, son of John'. The alternative view is that David II had tried to favour a cousin (and rival?) of John, in 1341, Angus MacIan of Ardnamurchan [Brown, Wars of Scotland, p. 270]. Either way, in 1341 David had tried to give Kintyre to a MacDonald, depriving Steward.

${ }^{55}$ David II seemingly ignored an invitation c.April 1344 to join Anglo-Norman rebels against the authorities in Ireland [G.O. Sayles, 'The Rebellious First Earl of Desmond', in J.A. Watt, J.B. Marshall and F.X. Martin eds., Medieval Studies presented to Aubrey Gwynn (Dublin, 1961), pp. 203-30, at 219-22.
} 
However, the Steward and his growing family proved resilient to royal intrusion and throughout 1342-3 David may have been obliged in turn to back down in his efforts to build an affinity and reassert royal authority in several localities. John MacDonald may thus have been a casualty of Stewart resurgence. At a Council in June 1343, again at Ayr, 'after diligent discussion and bearing the peace of our realm in mind', David reissued a revised form of the MacDonald patrimony grant to John 'de Yle [our dear cousin]' (the only occasion on which the Crown accorded John this honour in style) but this time reserving Kintyre and the Isle of Skye which were recovered by the Steward and Ross respectively. ${ }^{56}$ This decision surely hid pressure applied to David and his fledgling support by Steward, Campbell of Lochawe, Ross, John Menteith of Arran and Knapdale and perhaps even Ranald MacRuaridh and John Randolph, earl of Moray (released in early 1342 and who may have reclaimed Lochaber). ${ }^{57}$ Since the mid-1330s, the majority of these lords with west coast interests must have found themselves and their tenants increasingly ranged against cateran forces loyal to MacDonald aggressively expanding his lordship, including several MacDonald cadets, the MacLeans on Mull, the MacLeods on Lewis, the Mackintoshes in Lochaber and Mackinnons out of Iona (where they also exercised spiritual lordship under Lord John's control through Iona Abbey). ${ }^{58}$

The late fourteenth-century English chronicler, Henry Knighton - privy to David II's later complex diplomatic talks with Edward III - caught something of the sense of crisis this reverse represented:

\footnotetext{
${ }^{56}$ RRS, v, no. 72; Acts of the Lords of the Isles, pp. 207-8 [A2-A4]. The Bishop of the Isles now had his diocesenal seat on Skye. On 25 May 1342, William earl of Ross had secured a dispensation to wed Mary, sister of Angus Og [ibid., p. 242 [B23]].

${ }^{57} R R S$, v, nos 54, 69, 73; Penman, David II, pp. 98-100. David II suffered a similar reverse in 1342 in regard to Douglas and Stewart ambitions in Liddesdale and the earldom of Atholl [ibid., pp. 84-93]. In June 1343 the MacDonalds also lost land in Argyll to the MacNaughtons [RRS, vi, nos 485, 488].

${ }^{58}$ R.D. Oram, 'The Lordship of the Isles: 1336-1545', in D. Omand ed., The Argyll Book (Edinburgh, 2004), pp. 123-39, at 127-8; Acts of the Lords of the Isles, pp. lv-lxi.
} 
[In 1343] a dispute arose in Scotland between King David, who has made himself king, and John of Islay and others there. But King David bowed to their will, for if he had not he would have lost the kingdom... 59

Again, though, it is relevant to ask to what degree this royal act actually represented a reverse on the ground for MacDonald lordship. John's feud with the Stewarts and others in Kintyre and Skye seems to have continued, probably only drawing to a close when he agreed to wed Robert Steward's daughter, Margaret, in the late 1340s, possibly displacing his first (MacRuaridh) wife in the process. ${ }^{60}$ However, by then the political framework and regional lordship had again been revolutionised by David II's capture in battle against England at Neville's Cross on 17 October 1346. The latter was a campaign for which John of Islay had refused to respond to the Crown's summons, unlike Ranald MacRuaridh who had been murdered at the muster by his rival William, Earl of Ross. ${ }^{61}$

These dramatic events again benefitted MacDonald lordship and John moved to play the situation for all it was worth. As early as 4 November 1346 he entertained fresh overtures of alliance as dominus Insularum with envoys of Edward III. ${ }^{62}$ It was surely also not long after this that marriage talks began with the Steward, now King's Lieutenant, whose energies were drawn east to secure control of the central Scottish earldoms of Menteith, Strathearn and Fife and to stave off David II's attempts to broker his release from England through a treaty which altered the Scottish royal succession. As Richard Oram has emphasised, it was thus Stewart patronage which dictated the terms of much of this political marriage of

\footnotetext{
${ }^{59}$ Knighton's Chronicle, 1337-96, ed. G.H. Martin (Oxford, 1995), p. 41.

${ }^{60}$ A marriage dispensation was granted by the Papacy on 18 July 1350 [Vetera, p. 278; Acts of the Lords of the Isles, p. 242 [B25]].

${ }^{61}$ Chron. Wyntoun, vi, p. 174; Highland Papers, i, p. 17.

${ }^{62}$ Rot. Scot., i, p. 677.
} 
convenience. ${ }^{63}$ Yet this match did arguably invest MacDonald lordship over most of the Isles and key adjacent coastal holdings with its most substantive legitimacy to date.

Robert Steward was not only prepared to gift Kintyre and Knapdale as his daughter's dowry and to confirm John's inheritance and sub-infeudation of his first wife's Garmoran lands to their sons (hence the Clanranald MacDonalds), but also to concede MacDonald presence perhaps in Skye (so antagonising the Earl of Ross) and certainly in Lochaber and Moray bounding on Badenoch (which last the Steward acquired by taking John Randolph's widow, Euphemia, a sister of the Earl of Ross, as his second wife in 1355). ${ }^{64}$ It was therefore perhaps in this period that John MacDonald's consolidation of a great Council of the Isles, meeting in a purpose-built chamber with chapel at Finlaggan on Islay, really took root. ${ }^{65}$

These developments undoubtedly linked John of Islay in David II's mind with Robert Steward and other political troublemakers. In August 1354 David and his procurators named Lord John along with the Steward, his lieutenant Sir Thomas Murray, William Lord of Douglas and the earls of March and Ross, as potential hostages to be surrendered if the Scots defaulted on the ransom instalments then proposed for the Scottish king's release. ${ }^{66}$ Although these talks were aborted, David was also surely directly involved in the remarkable return to Scotland sometime c.1350-3 of John Macdougall, known as Gallda (the 'Foreigner'), claimant to his family's disinherited Argyll lands. From his own exile, the king may have had a hand as early as 1352 in Macdougall's marriage to his niece, Janet (daughter of Thomas

${ }_{63}^{63}$ Oram, 'Lordship of the Isles: 1336-1545', p. 124.

${ }^{64}$ A. Grant, 'Scotland's 'Celtic Fringe' in the Late Middle Ages: the MacDonald Lords of the Isles and the Kingdom of Scotland', in Davies ed., The British Isles, 1100-1500, pp. 118-41, at 126-8; Boardman, The Campbells, pp. 62-4.

${ }^{65}$ D.H. Caldwell and G. Ewart, 'Finlaggan and the Lordship of the Isles: An Archaeological Approach', SHR, lxxii (1993), pp. 146-66. In 1349, documentation confirming William Russell as bishop of the Isles named William Montagu of Man, Robert Steward 'of Bute' and 'Johanni Moac Dofnald domino de Ile' as the most powerful lords of the diocese [Chronicle of Man and the Sudreys (1257-1376), ed. P.A. Munch (Christiana, 1860), pp. 148, 165-6 [Appendix no. 17]].

${ }^{66}$ CDS, iii, no. 1576; Foedera, iii, p. 277. 
Isaac and Matilda Bruce), just as he would intervene in noble marriages in Bothwell, Menteith, Fife, Carrick, Mar and Ross during his ‘second reign'.

On 23 January 1358, shortly after his release to Scotland, David would confirm John Macdougall's possession of his family's lands in Lorn. ${ }^{67}$ David also extended patronage about this time to Macdougall's regional allies, Gilbert of Glasserrie (another former Balliol Man) and Archibald Campbell of Lochawe. ${ }^{68}$ Such was David's personal favour to John Macdougall at this time that historians have speculated that David might even have considered his issue as another Anglophile alternative to a Stewart royal succession. ${ }^{69}$ More realistically, the king could at least hope to encourage Macdougall and his neighbours to make life difficult for MacDonald; as Abbot Walter Bower's later chronicle put it: 'by persuading and inducing one chieftain to kill or capture [another one]... 70

It says much for lingering loyalties to the Macdougalls after a forty year absence, allied to resentment of aggressive MacDonald lordship, that John Gallda was able to recover a core of lands. John of Islay seems to have had no option but to recognise this reality as long as Macdougall was at the same time willing to concede his regional dominance. On 8 September 1354, indeed, the two men had sealed a detailed bond of peace. ${ }^{71}$ This saw MacDonald retain control over specified islands, castles and churches within the former Macdougall patrimony first forfeited by Robert I. As such, MacDonald may have viewed the declaration to treat his former enemy as a 'brother' as a pragmatic concession banked against

\footnotetext{
${ }^{67} R R S, \mathrm{v}$, no. 165.

${ }^{68}$ Ibid., nos 166, 183-4; RMS, i, App. ii, nos 1136-7, 1139, 1144, 1171-2, 1183, 1216-17; J.W.M. Bannerman, 'The Lordship of the Isles - Historical Background', in K.A. Steer and Bannerman eds., Late Medieval Monumental Sculpture in the West Highlands (Edinburgh, 1977), pp. 204-8; Highland Papers, i, pp. 75-8, and ii, pp. 119, 142-3.

${ }^{69} E R$, ii, pp. 106, 114, 173; Boardman, 'The Tale of Leper John', p. 232. Fordun's contemporary annals insert the Macdougall-Bruce marriage alongside material for 1350-2 [Chron. Fordun, i, p. 369].

${ }^{70}$ Chron. Bower, vii, pp. 359-61.

${ }^{71}$ Highland Papers, i, pp. 76-8; Acts of the Lords of the Isles, pp. xxvii-xxviii, 5-8.
} 
the return of David II (one possibly mediated, again, by Robert Steward). In doing so the Lord of the Isles perhaps remained confident of his ability, as ever, to limit the immediate impact of Crown interference on the ground in the west. After all, he certainly made sure to balance his kindred's prospects - as in past crises - in the opposing direction. In October 1357 he would be included in the Treaty of Berwick for David's release as an ally of Edward III. This ensured MacDonald exemption from both the taxation necessary to raise annual ransom instalments (at first, 10,000 merks a year for ten years) and nomination this time as a valuable hostage if any such instalment was defaulted: he also secured trading licences in England and Ireland for six of his named merchants (including a John of Portrush and a William of Ulster). ${ }^{72}$

However, Lord John's actions may also betray his extreme nervousness about a controversial, unpredictable element introduced to Scottish political affairs by the second Bruce king by c.1350 and pursued with something close to obsession over the next two decades. In lieu of a hefty ransom, David II sought to buy off the English with a place for one of Edward III's younger sons in the Scottish royal succession, at once undermining the Stewarts and boosting royal authority over wider regional magnate interests by reducing the need for regular parliamentary taxation. This unsettling plan was discussed and rejected by the Scottish political community on at least three occasions - 1352, 1359 and 1364 - but still had substantial support from elements across all three estates, encouraging David to persist. At first, Edward III's second son, David's nephew, John of Gaunt, married in to the Duchy of Lancaster by 1359 , seemed the favoured prince for this deal. Yet both English chronicler Henry Knighton and the Scotichronicon of Abbot Bower, the latter writing in the 1440s but with access to royal records and narrative material contemporary to David's reign, assert that

\footnotetext{
${ }^{72} C D S$, iii, nos 1606, 1639, 1657; RRS, v, nos 148-50. Tellingly in May 1357, Lord John had been in the frame again as a hostage [CDS, iii, no. 1629]. John also had a safe-conduct to England from autumn 1357 [Rot. Scot., i, p. 811].
} 
in fact Edward's third son, Lionel, Duke of Clarence (born 1338), was considered as an alternative heir presumptive. ${ }^{73}$

This twist on the Bruces' co-operation with the Anglo-Norman Ulster lordship of 1286, c.1302 and the 1320s might thus have impacted upon the MacDonald lordship as well as the Stewartry. For from 1347 Lionel was fourth Earl of Ulster as well as Lord of Connacht, wed to David II's second cousin, Elizabeth de Burgh, daughter of the slain third earl, and appointed as Lieutenant of Ireland in $1361 .^{74}$ If David's proposal could be brought to fruition, the resulting alliance - or even any more minor agreements of lordship concluded on its frayed robe-tails - must pose a direct threat to the MacDonalds' continued galloglass activities throughout the Irish Sea world, as well as their regional lordship over the Hebrides and Argyllshire coast.

That these issues did indeed bleed into Bruce-MacDonald-Stewart relations in the 1360s is suggested by John of the Isles' possible involvement in the 'Three Earls' rebellion' of the Stewarts, Douglas and March in spring 1363, although the evidence for this is slight. The rising was provoked in part by David's plans to approach Edward III about reviving his succession-peace plan and once crushed saw the Bruce king confirm to 'John de Insulis', from Edinburgh on 4 July 1363 (just before David left once more for London), all his existing holdings, perhaps by way of pardon. ${ }^{75}$ However, stronger evidence of MacDonald opposition to David's diplomacy is highlighted by the king's further proposal, to a select 'congregation' of mainland nobles at Perth in July 1365 (including John of Lorn and Campbell of Lochawe),

${ }^{73}$ Chron. Bower, vii, p. 323; Penman, David II, pp. 331-3; Boardman, The Campbells, pp. 75-7. The 1365 plan included proposals to cede $£ 2,000$ worth of Scottish territory to this English Prince, including Galloway and the Isle of Man, a grant which thus could have united the historically linked lordships of northern Ireland and south-west Scotland. Knighton asserts that Edward Balliol resigned his rights in Scotland to Lionel [Knighton's Chronicle, pp. 136-7].

${ }_{74}$ W.M. Ormrod, Edward III (London, 2012), pp. 317-8.

${ }^{75}$ RMS, i, no. 156 and App. ii, no. 1466; Acts of the Lords of the Isles, p. 208 [A5]; RRS, v, no. $297[\mathrm{G}]$. 
that a mutual military alliance be forged with England which would see 'fighting men of those people of Scotland who are within the borders of Scotland and Ireland' obliged to serve the English Crown in Ireland for three months a year for between five and 15 years. ${ }^{76}$ The dispatch of magnates like John of Islay, Robert Steward and William Earl of Ross on annual military service in Ireland would have been of understandable appeal to David and his close councillors. Yet it may also have been a term sought anxiously and in vain by Clarence's troubled regime in Dublin. The evidence points to continued mercenary activity throughout this period: for 1366-8, the Connacht annalist recorded MacDonald galloglass arriving to take part in O'Neill conflict (with an 'Alexander Mac Domnaill...constable of the gallowglasses' killed); for 1367, after Anglo-Scottish talks had collapsed, near-contemporary English chronicler, John of Reading, reported that Scottish forces plundered Ulster. ${ }^{77}$

As with many of the king's plans c.1350-71 there was more smoke than fire in David's schemes for the west. Unlike his father, the second Bruce monarch did not venture into the Gael, allowing strongholds like Tarbert to fall out of use and failing to provide allies like Macdougall with personal support. ${ }^{78}$ Between 1366 and 1370 John of Islay was cited on several occasions for 'contumacious absence' from Parliament alongside the Earl of Ross and, tellingly, Macdougall. ${ }^{79}$ The Parliament at Scone in July 1366 had seen the estates demand that 'those rebels, namely of Atholl, Argyll, Badenoch, Lochaber and Ross...should be arrested by the king and his armed force to undergo common justice (probably to deal with persistent cattle raiding) and particularly for paying off the [ransom] contribution' ${ }^{80}$ David

\footnotetext{
${ }^{76}$ RPS, $1365 / 7 / 1-3$.

77 Annals of Connacht, pp. 328-9, 334-5; Chronica Johannis de Reading et Anonymi Cantuarensis, 1346-57, ed. J. Tait (Manchester, 1914), p. 184; Nicholls, 'Scottish Mercenary Kindreds in Ireland, 1200-1600', p. 93.

${ }^{78}$ The last recorded Exchequer payments for maintenance at Tarbert relate to the upkeep of the park there in 1330 [ER, i, pp. 207, 213, 239, 287].

${ }^{79}$ RPS , 1366/7/1; 1368/6/1; 1369/3/1; 1370/2/1.

${ }^{80}$ Ibid., 1366/7/10-11 and 15.
} 
and his councillors thus sought to use a simultaneous reassessment of taxable lands and goods in 1366-7 to strip the MacDonalds of their exemption from the ransom levies and to spread the cost of royal finance more evenly (at a time when in fact David had not made a payment to England since 1362 and negotiated the first of two cost reductions and term extensions with Edward III). ${ }^{81}$

However, later in the year Parliament could only record that the royal assessors had been denied access to MacDonald lands (valued in the thirteenth century at $£ 1,320$ ) just as they had been repelled from the holdings of the Steward, the Earl of Ross, Macdougall and the Campbells of Lochawe. ${ }^{82}$ In the following year, the Crown seemingly sought to apply a Parliamentary revocation of royal grants to once again target the lands of these recalcitrant western lords: MacDonald was charged $£ 400$ in re-entry for Lewis, Lochaber and Garmoran, a blatantly higher rate than the fines asked of David's supporters and probably never paid by John of Islay. ${ }^{83}$ All these efforts spoke ultimately to the continued impotence of the Crown in dealing with the Lordship.

It was not in fact until the last two years of his reign that David was able to demonstrate some authority over Lord John and it is revealing of the balance of political power after $1346 / 1357$ that this first required the king and a realigned royal party to gain a clear stranglehold on the activity of Robert Steward. The heir presumptive, briefly arrested in autumn 1368 along with his fourth son, Alexander of Badenoch, and temporarily deprived of

\footnotetext{
${ }^{81}$ Ibid., 1366/7/18.

${ }^{82}$ In addition, the only exchequer intromission from the sheriffship of Argyll for David II's later reign was a small sum of 'arrears', £39, returned for Jan. 1366 to Jan. 1367 [ER, ii, p. 256]. Similar small sums were also returned for the contribution by the bishopric of the Isles. ${ }^{83} R P S, 1368 / 2 / 1-2 ; R R S, \mathrm{v}$, nos 387-8, 389-90.
} 
his title to Strathearn, had to stand surety for his son-in-law when John MacDonald submitted in person to King David at Inverness on 15 November $1369 .^{84}$

Through this act John acknowledged past 'negligences' in his execution of justice and promised to obey Crown officers and contribute to the ransom, surrendering two hostages to royal ward. ${ }^{85}$ On vellum this seems an impressive assertion of monarchy. It fulfilled Parliament's restated plea of March 1369 that David 'compel and force with a firm hand in diverse and convenient places John of the Isles and his sons, and other adhering to him...to come to the king's obedience and stand to law, and undergo services and charges with mainlanders. ${ }^{86}$ In anticipating strategies against the Lordship which would later be deployed by James I in the same location, David was accompanied to his northernmost castle by an impressive retinue of prelates and chivalric nobility headed by Douglases, Dunbars, Keiths, Lindsays, Erskines and John Macdougall of Lorn who by 1370 would be reinvested as a royal agent in the west through grants of the lordship of Glen Lyon and as baillie of Dull. ${ }^{87}$

Nevertheless, as with a number of David II's confrontations of his regional magnates, there may have been only limited bite to this submission. As in the past David may have been prevented - by the general nervousness of the Estates and the increasing inevitability of a Stewart succession to the childless Bruce king - from going as far as he had really desired in punishing and, surely, forfeiting the Steward and MacDonald of key parts of their patrimony. Indeed, the terms of submission may reflect the Steward's continued ability to limit royal action. The indenture crucially styles John as 'dominus Insularum' (not simply 'de Yle' or 'de Insulis' as in 1343 then 1363). It required John's grandson, Angus, the son of his late

\footnotetext{
${ }^{84}$ Acts of the Lords of the Isles, pp. 8-10 [no. 6].

${ }^{85}$ ER, ii, p. 344. Alexander III had also taken heirs as hostages from Angus Mòr in 1263 [ibid., i, p. 5] ; so too had Edward III and Edward Balliol in 1336.

${ }^{86}$ RPS, 1369/3/5-7 and 10 [Highland violence also preventing payment to the Norse of the annum for the Western Isles].

${ }^{87} R M S$, i, no. 237 and App. ii, no. 1376; ER, ii, p. 295.
} 
eldest son, John, from his first marriage (who had married a Campbell of Lochawe), along with another bastard son, Donald, to be submitted as hostages, thus not any of the sons by John's second, Stewart wife. The hostages were kept, moreover, at Dumbarton castle in the care of Sir Robert Erskine, a key royal councillor but also a Stewart tenant and a lord who would prove himself well able to serve both Crown and heir presumptive.

Thus there may have been a large element of compromise attached to the MacDonald submission and it really only allowed David and his supporters to further their mainland territorial agenda in Moray, Lochaber and the Great Glen. The extant royal chamberlain's rolls for 1370-71 certainly return handsome sums intromitted by officials for the former Randolph earldom (although it is not clear if this included Lochaber) and northern Perthshire, but still nothing from the Argyll coast and the Isles. ${ }^{88}$ Finally, MacDonald would once more be amongst those cited for 'contumacious absence' from the very next Parliament at Perth, just over three months later, in late February $1370 .{ }^{89}$ This same assembly urged that in future David spread the cost of supporting the royal household by undertaking 'a stay, at certain and opportune times, in the highland regions, in which he ought and will be able to have more useful prises and a better market price, and similarly to pacify the country and to punish malefactors': the MacDonald lands were specifically named in this context alongside those of the Stewarts in Kintyre, Knapdale and Arran, Macdougall of Lorn and the Campbells of Lochawe. ${ }^{90}$

Whatever further action against John of the Isles David II may have intended, his itinerary after Spring 1370 suggests that his health was already in decline and for the remainder of his reign he prioritised the Bruce legacy elsewhere, including a last journey to England. David's death on 22 February 1371 confirmed John of the Isles' evasion of a Bruce

\footnotetext{
${ }^{88} E R$, ii, pp. 342, 352, 363, 432.

${ }^{89}$ RPS, $1370 / 2 / 1$.

${ }^{90}$ Ibid., $1370 / 2 / 8$ and 32.
} 
monarchy vendetta and the wisdom (and cost) of alignment with the Stewarts. Amongst Steward's acts as Robert II in the first few years of his reign would be confirmations of MacDonald's former MacRuaridh lands as well as re-grants of Lochaber and Kintyre to John and his now royal wife, Margaret Stewart. ${ }^{91}$

\section{Conclusion}

Through the 'long-fourteenth century', the MacDonald Lordship of the Isles undoubtedly emerged as the dominant power in the west and leading exponent of Gaelic militarised lordship and culture. In doing so, the MacDonald kindred and its allies remained removed from the mainland in many important ways. As a result, the canon of Scottish chroniclers would comment, if with mixed sympathies, on the striking otherness of the Lordship and its caterans during the reigns of the early Stewart monarchs. ${ }^{92}$

Nevertheless, the difficult course of the Wars of Independence meant that successive MacDonalds had not been able to avoid, and indeed had sought to exploit and experience, interaction and integration with the wider political communities of both the Scottish kingdom and the British Isles. ${ }^{93}$ Like the Bruces, Stewarts and other rising mainland dynasties, the MacDonalds' success across this period owed as much to their pragmatic choices of lordship - timely switches of adherence, advantageous marriages and negotiated settlements over land and inheritance - as it did to their capacity for violent action; perhaps more so in dealings outwith their regional concerns. Moreover, like the Campbells, the MacDonalds had also benefitted from both Bruce and Stewart sponsorship.

\footnotetext{
${ }^{91}$ Acts of the Lords of the Isles, pp. 209-11 [A6-A10]. The Stewarts would also absorb Macdougall of Lorn's lands [Boardman, 'The Tale of Leper John'].

${ }^{92}$ Chron. Fordun, i, p. 24; Chron. Bower, i, p. 185; Grant, 'Scotland's Celtic Fringe', pp. 118-20.

${ }^{93}$ Oram, 'Lordship of the Isles: 1336-1545', pp. 123-4.
} 
In the context of the 1370 s, then, there was surely some expectation of the potential for further MacDonald engagement with royal government and Scottish aristocratic society: that the Gael could be 'loyal and obedient to their king and country, and provided they [are] well governed they are obedient and ready enough to respect the law. ${ }^{94}$ One telling hint of this is the only recorded ransom 'contribution' payment by John of the Isles to the royal Chamberlain, a sum of $£ 1336 /-8 \mathrm{~d}$, intromitted in 1373 . $^{95}$

Yet if this was the hope of some in a generation which now knew John of the Isles as the son-in-law of the new king and brother to several princes of the blood, it was to remain sorely unfulfilled and prove a short aberration. Throughout the majority of the rule of the Bruce monarchs - over six decades, since the first expulsion of the Macdougalls and then the collapse of the Irish campaign in 1318 - the MacDonalds had found themselves at odds with Scottish monarchy. By the 1360s, repeated Parliamentary calls for Crown intervention in the west confirmed the more dramatic view that the 'Highlanders and people of the Islands...are a wild and untamed race, primitive and proud, given to plunder and the easy life.... ${ }^{96}$ In this regard, it was a final irony that in forcing William, Earl of Ross, to resign his earldom and daughter's hand in 1370 to a non-Gael placeman, Sir Walter Leslie, the last Bruce king would also be the one to open the door to further MacDonald expansion east, on a collision course with the Badenoch Stewarts and on a high road to Harlaw.

\footnotetext{
${ }^{94}$ Chron. Fordun, i, p. 24.

${ }^{95}$ ER, ii, p. 431.

${ }^{96}$ Chron. Fordun, i p. 24.
} 